ElementerIs: Jurnal Ilmiah Pendidikan Dasar Islam

Volume 2 Nomor 1 Mei 2020

e-ISSN: 2655-6324

\title{
PENINGKATAN MINAT BELAJAR AKIDAH AKHLAK ANAK KELAS V MI/SD MELALUI METODE QUICK ON THE DRAW
}

\author{
Nur Nafisatul Fithriyah', Nur Latifah ${ }^{2}$, Khusnul Mu'alifah ${ }^{3}$ \\ Pascasarjana UIN Sunan Ampel Surabaya \\ e-mail: 1nurnafisatulfithriyah@gmail.com, 2 NurLatifah389@gmail.com, \\ 3khusnulifah@yahool.com
}

Diterima: 15 Juni 2020 | Direvisi: 29 Juni 2020 | Disetujui: 1 Juli 2020 (C) 2020

Pendidikan Guru Madrasah Ibtidaiyah Fakultas Agama Islam Universitas Islam Malang

\begin{abstract}
Abstrak
Student learning interest is very low with the results of student learning interest questionnaire that is classified as low and very low 26 students with a percentage of $57.78 \%$. One solution to overcome this is through the implementation of the quick on the draw strategy. The purpose of this study are: 1) Determine the interest in learning of fifth grade MI Darul Hidayah Tulangan Sidoarjo students before applying the quick on the draw strategy. 2) Knowing the application of the quick on the draw strategy. 3) Knowing the increase in student learning interest after applying the quick on the draw strategy. The research method used is CAR using the Kurt Lewin model, which each cycle consists of 4 main components. Data collection techniques used are tests of student understanding, attitude assessment, observation, interviews, and documentation.The results of the study are as follows: 1) Student learning interest is low. 2) The implementation of the Quick on The Draw strategy obtained the results of observations of student activity in the first cycle of 65 (good) and increased in the second cycle to 90 (very good). 3) Student learning interest after applying the strategy has increased with pre cycle results of $42.22 \%$ with $46.67 \%$ learning outcomes. Cycle I obtained $66.67 \%$ interest in learning outcomes, $68.89 \%$ learning outcomes. In the second cycle increased to $91.11 \%$ and $88.89 \%$ learning outcomes in the excellent category and have met the specified performance indicators.
\end{abstract}

Keywords: Interest, Strategy, Quick On The Draw

\begin{abstract}
Abstrak
Minat belajar siswa sangat rendah, berdasarkan hasil angket minat belajar dari 26 siswa tersebut mendapatkan persentase 57,78\%. Salah satu solusi untuk mengatasinya adalah melalui penerapan strategi quick on the draw. Tujuan penelitian ini adalah: 1) Menentukan minat belajar siswa kelas V MI Darul Hidayah Tulangan Sidoarjo sebelum menerapkan strategi quick on the draw. 2) Mengetahui penerapan strategi quick on the draw. 3) Mengetahui peningkatan minat belajar

This work is licensed under Creative Commons Attribution Non Commercial 4.0 International License Available online on: http://riset.unisma.ac.id/index.php/je
\end{abstract}


Nur Nafisatul Fithriyah, Nur Latifah, Khusnul Mu'alifah

siswa setelah menerapkan strategi quick on the draw. Metode penelitian yang digunakan adalah CAR menggunakan model Kurt Lewin, yang setiap siklusnya terdiri dari 4 komponen utama. Teknik pengumpulan data yang digunakan adalah tes pemahaman siswa, penilaian sikap, observasi, wawancara, dan dokumentasi. Hasil penelitian adalah sebagai berikut: 1) Minat belajar siswa rendah. 2) Implementasi strategi Quick on The Draw memperoleh hasil pengamatan aktivitas siswa pada siklus pertama dari 65 (baik) dan meningkat pada siklus kedua menjadi 90 (sangat baik). 3) Minat belajar siswa setelah menerapkan strategi mengalami peningkatan dengan hasil pra siklus sebesar 42,22\% dengan hasil belajar 46,67\%. Siklus I memperoleh minat belajar 66,67\% pada hasil belajar, 68,89\% hasil belajar. Pada siklus kedua meningkat menjadi 91,11\% dan hasil belajar 88,89\% dalam kategori sangat baik dan telah memenuhi indikator kinerja yang ditentukan.

Kata kunci: Minat, Strategi, Quick On The Draw

\section{Pendahuluan}

Mata Pelajaran Aqidah Akhlak merupakan cabang dari pendidikan agama Islam (Majid dan Andayani, 2005: 130). Ruang lingkup mata pelajaran Aqidah Akhlak Di Madrasah Ibtidaiyah meliputi aspek akidah (keimanan), aspek akhlak, aspek adab Islami dan aspek kisah teladan. Karena pembiasaan aqidah, akhlak dan adab Islami dalam kehidupan sehari-hari yang ada di lingkungan peserta didik MI/SD itu penting, hendaknya pembelajaran Aqidah Akhlak pada jenjang pendidikan dasar harus sesuai dengan karakteristik peserta didik, sehingga mampu mencakup isi atau materi yang akan diajarkan.

Pembelajaran yang baik harusnya dilakukan dengan memperhatikan tujuan pembelajaran, karakteristik peserta didik, materi yang diajarkan, dan sumber belajar yang tersedia. Kenyataannya proses pembelajaran Aqidah Akhlak di tingkat MI/SD selama ini lebih menekankan pada penguasaan materi pelajaran sebanyak mungkin, sehingga pembelajaran hanya bersifat satu arah. Proses seperti ini membuat kegiatan belajar di kelas menjadi kaku dan tidak memberikan kesempatan bagi peserta didik untuk belajar lebih aktif. Kegiatan belajar cenderung diwarnai ceramah. Akibatnya peserta didik menjadi pasif karena mereka menganggap pelajaran Aqidah Akhlak adalah pelajaran mendengarkan. Sehingga hasil belajar yang dicapai juga tidak optimal. Hal ini terjadi pada peserta didik Kelas V MI Darul Hidayah Tulangan Sidoarjo. Kegiatan belajar peserta didik hanya diberikan satu arah yakni dengan metode ceramah. Pembelajaran yang lebih menekankan pada metode ceramah membuat peserta didik merasa lebih cepat jenuh sehingga kegiatan belajar cenderung membosankan. Kegiatan pembelajaran semacam ini justru akan membuat peserta didik kurang menguasai konsep materi yang diajarkan.

ElementerIs: Volume 2 Nomor 1 Mei 2020 
Nur Nafisatul Fithriyah, Nur Latifah, Khusnul Mu'alifah

Selain itu penggunaan strategi yang kurang tepat juga mempengaruhi keaktifan peserta didik. Sehingga menjadi tantangan tersendiri bagi guru agar menemukan strategi yang tepat dalam proses belajar mengajar agar dapat menumbuhkan semangat peserta didik dan meningkatkan hasil belajar sesuai dengan KKM yang ditentukan.

Berdasar wawancara dengan guru Aqidah Akhlak, permasalahan yang dihadapi dalam pembelajaran ini adalah hasil belajar peserta didik banyak yang belum mencapai KKM (Kriteria Ketuntasan Minimal) yang ditentukan yakni sebesar 75. Berdasarkan hasil wawancara dengan guru mata pelajaran Aqidah Akhlak di MI Darul Hidayah Tulangan Sidoarjo, diketahui bahwa hasil belajar peserta didik kelas V pada materi akhlak terpuji masih rendah. Dari 45 peserta didik hanya 46,67 \% dari jumlah peserta didik yang telah mencapai KKM yang telah ditentukan. Sedangkan 53,33 \% dinyatakan belum berhasil. Kelas dinyatakan tuntas, apabila jumlah peserta didik yang mencapai KKM 80\%. Oleh karena itu diperlukan strategi yang tepat untuk dapat mengatasi masalah rendahnya hasil belajar peserta didik kelas $\mathrm{V}$ pada materi akhlak terpuji. Untuk melaksanakan tugas secara professional, seorang guru memerlukan wawasan yang mantap tentang kemungkinan-kemungkinan strategi pembelajaran sesuai dengan tujuan-tujuan belajar, baik dalam arti efek intruksional maupun efek pengiring, yang ingin dicapai berdasarkan rumusan tujuan pendidikan yang utuh, di samping penguasaan teknis di dalam mendesain sistem lingkungan belajar mengajar dan mengimplementasikan secara efektif apa yang telah direncanakan di dalam desain intruksional (Ahmadi, 2011:13). Strategi yang diperlukan adalah yang mampu menumbuhkan keaktifan peserta didik secara menyeluruh dalam proses pembelajaran. Salah satu strategi yang dapat digunakan adalah quick on the draw.

\section{Metode Penelitian}

Penelitian ini menggunakan Penelitian Tindakan Kelas (PTK). PTK dipilih dalam penelitian ini sebab peneliti ingin meningkatkan kualitas pembelajaran secara khusus dalam hal meningkatkan minat belajar peserta didik di MI Darul Hidayah Tulangan Sidoarjo. Penelitian ini didesain untuk membantu guru dalam mengetahui permasalahan yang terjadi di dalam kelasnya. Informasi yang didapatkan oleh guru ini kemudian dijadikan peneliti untuk mempertimbangan dalam mengambil keputusan yang berkaitan dengan strategi yang akan diterapkan. PTK ini bertujuan untuk meningkatkan profesionalisme guru, minat belajar peserta didik dikelas atau sekolah secara keseluruhan. PTK ini memadukan antara penelitian kualitatif dan kuantitatif. Dalam pelaksanaan PTK ini menggunakan Model Kurt Lewin. Menurut Kurt Lewin konsep pokok action research terdiri dari empat komponen, yaitu: Planning (Perencanaan), acting (Tindakan), observing (Pengamatan), dan reflecting (Refleksi). 
Nur Nafisatul Fithriyah, Nur Latifah, Khusnul Mu'alifah

Penelitian ini dilakukan pada kelas V MI Darul Hidayah Tulangan Sidoarjo dalam mata pelajaran Aqidah Akhlak khususnya materi akhlak terpuji. Pemilihan pada kelas atas ini dilakukan dengan pertimbangan bahwa minat belajar peserta didik di kelas atas masih perlu ditingkatkan sesuai dengan hasil observasi yang dilakukan peneliti. Selain itu pembelajaran dengan menggunakan strategi quick on the draw masih belum diterapkan pada sekolah Darul Hidayah Tulangan Sidoarjo.

Adapun rencana tindakan pada siklus I dan II akan diuraikan sebagai berikut: Perencanaan (Planning), Tindakan (acting), Pengamatan (observing), Refleksi (Reflecting). Teknik pengumpulan data pada penelitian ini agar bisa mendapatkan data yang benar-benar valid. Maka peneliti melakukan pengumpulan data dengan cara sebagai berikut: wawancara, observasi, angket, dan dokumentasi. Analisis data pada penelitian ini merupakan langkah yang sangat penting. Karena dari hasil ini dapat digunakan untuk menjawab rumusan masalah yang diajukan peneliti. Dalam menganalisis data-data tentang penerapan strategi quick on the draw yang dilakukan dengan cara mengobservasi aktivitas guru dan aktivitas peserta didik digunakan rumus sebagai berikut.

$$
\text { Skor akhir }=\frac{\text { skor perolehan }}{\text { skor maksimal }} \times 100
$$

Dengan menggunakan rumus di atas, peneliti menggunakan kriteria sebagai berikut:

$100-76=$ Sangat Baik

$75-51=$ Baik

$50-26=$ Tidak Baik

$25-0$ = Sangat Tidak Baik

Adapun untuk memberikan prosentase pada angket tentang minat belajar dengan penerapan strategi quick on the draw, peneliti menggunakan rumus sebagai berikut:

$$
P=\frac{F}{X} \times 100 \%
$$

Keterangan:

$\mathrm{P}=$ Prosentase

$\mathrm{F}=$ Frekuensi

$\mathrm{X}=$ Jumlah Peserta didik

Dengan menggunakan rumus di atas, penulis menggunakan kriteria sebagai berikut:

$100-86=$ Minat belajar peserta didik sangat tinggi

$85-71=$ Minat belajar peserta didik tinggi

$70-51=$ Minat belajar peserta didik rendah 
Nur Nafisatul Fithriyah, Nur Latifah, Khusnul Mu'alifah

$50-0=$ Minat belajar peserta didik sangat rendah

Adapun pemberian skor pada angket tentang penerapan strategi quick on the draw dalam minat belajar, peneliti menggunakan ketentuan sebagai berikut:

1. Pernyataan positif : Sangat Setuju $=4$; Setuju $=3$; Tidak Setuju $=2$; Sangat Tidak Setuju $=1$

2. Pernyataan negatif : Sangat Setuju $=1$; Setuju $=2$; Tidak Setuju $=3$; Sangat Tidak Setuju $=4$

Sedangkan untuk kriteria minat belajar peserta didik menggunakan pedoman sebagai berkut:

1. Skor batas bawah kategori sangat tinggi/sangat baik adalah $0,80 \times 80=64$.

2. Skor batas bawah kategori tinggi/baik adalah $0,70 \times 80=56$.

3. Skor batas bawah kategori rendah/kurang adalah $0,50 \times 80=40$.

4. Skor batas bawah kategori sangat rendah/sangat kurang adalah $<40$.

Berdasarkan petunjuk pelaksanaan belajar mengajar, seorang peserta didik dikatakan mencapai ketuntasan atau berhasil apabila telah mencapai KKM dengan nilai 75. Sedangkan pembelajaran dapat dikatakan tuntas apabila di dalam kelas tersebut terdapat $80 \%$ peserta didik yang telah mencapai nilai lebih dari sama dengan 75 .

Untuk menghitung prosentase ketuntasan belajar digunakan rumus sebagai berikut:

$$
\text { Persentase }=\frac{\text { Jumlah peserta didik yang tuntas belajar }}{\text { Jumlah peserta didik }} \times 100 \%
$$

Data dari hasil analisis tersebut selanjutnya dapat disajikan melalui grafik, tabel, perhitungan modus, median, mean, diagram lingkaran, perhitungan desil, persentil, perhitungan penyebaran data melalui perhitungan rata-rata dan standar deviasi, dan diberikan pembahasan.

\section{Hasil Penelitian}

Berdasarkan hasil penelitian dan analisis data yang ada dapat dilihat adanya peningkatan minat belajar peserta didik kelas V MI Darul Hidayah Tulangan Sidoarjo. Pada kegiatan pra tindakan terlihat peserta didik belum siap mengikuti kegiatan pembelajaran. Beberapa peserta didik bermain dengan teman atau alat tulisnya. Ketika proses pembelajaran guru menggunakan metode atau strategi ceramah saja. Peserta didik mendengarkan dan guru menjelaskan, akibatnya peserta didik menjadi bosan. Guru dalam mengajar juga lebih dominan berada di depan, sehingga peserta didik yang duduk di belakang kurang menerima perhatian dari guru.

Pada saat proses pembelajaran, guru hanya menerangkan pelajaran kepada peserta didik. Untuk evaluasi guru menginstruksikan peserta didik untuk 
Nur Nafisatul Fithriyah, Nur Latifah, Khusnul Mu'alifah

mengerjakan soal, evaluasi ini selanjutnya dikoreksi bersama dan dijadikan tugas rumah. Guru jarang memberikan pertanyaan kepada peserta didik begitupun peserta didik juga jarang mengajukan pertanyaan. Untuk mengetahui minat belajar peserta didik terhadap mata pelajaran Aqidah Akhlak materi akhlak terpuji peneliti menggunakan angket. Dari angket yang dibagikan ke peserta didik, menunjukkan bahwa minat belajar peserta didik terhadap mata pelajaran Aqidah Akhlak materi akhlak terpuji dalam kategori sangat rendah. Selanjutnya peneliti menyiapkan perencanaan untuk kegiatan siklus I yakni menganalisis kurikulum, merancang materi pembelajaran, menetapkan indikator ketercapaian hasil belajar, membuat silabus, menyiapkan bahan ajar dan instrumen yang dibutuhkan. Pada kegiatan siklus I diterapkan strategi quick on the draw yang dimaksudkan untuk meningkatkan minat belajar peserta didik.

Berdasarkan data hasil penelitian untuk minat belajar peserta didik kategori tinggi dan sangat tinggi pada pra tindakan dan siklus I mengalami peningkatan. Hal tersebut terjadi karena adanya perhatian peserta didik terhadap materi yang dijelaskan oleh guru. Selain itu, pada siklus I peserta didik tidak hanya menjadi pendengar saja, tapi mereka ikut terlibat dalam kegiatan belajar mengajar yaitu dengan berkelompok. Peserta didik terlihat sangat aktif ketika pembagian kelompok, karena peserta didik jarang dibagi menjadi kelompok ketika proses pembelajaran. Namun masih ada peserta didik tidak memperhatikan saat guru menjelaskan materi karena guru menjelaskan dengan nada bicara dan intonasi yang kurang jelas. Peserta didik juga masih terlihat bingung ketika melakukan permainan yang ada dalam strategi quick on the draw. Sehingga sebagian peserta didik tidak berpartisipasi sepenuhnya. Hal ini dikarenakan peserta didik belum memahami pengaplikasian strategi quick on the draw. Peserta didik juga masih belum terbiasa dengan strategi ini.

Pada kegiatan akhir guru menyimpulkan apa yang sudah dipelajari dan memberikan umpan balik kepada peserta didik yang kurang memperhatikan. Pemberian tugas rumah, informasi tentang pertemuan selanjutnya dan merapikan tempat duduk dari guru hanya sebagian peserta didik yang memperhatikan karena intonasi suara dan interaksi kepada peserta didik kurang tetapi pada kegiatan berdo'a dan salam peserta didik sangat antusias. Guru dapat memberikan motivasi pada peserta didik sehingga peserta didik memiliki suatu kebanggaan yang telah diminati. Dengan adanya siklus I peneliti mengetahui kekurangan-kekurangan dalam pembelajaran dan peneliti melakukan perbaikan-perbaikan yang diterapkan pada siklus II. Guru menggunakan media gambar untuk membantu ketika menjelaskan materi. Guru menjelaskan aturan permainan dengan nada dan 
Nur Nafisatul Fithriyah, Nur Latifah, Khusnul Mu'alifah

intonasi yang jelas. Agar mudah dipahami oleh peserta didik dan peserta didik tidak bingung ketika melakukan permainan. Guru juga mengkondisikan waktu.

Berdasarkan data dari hasil penelitian minat belajar peserta didik kategori tinggi dan sangat tinggi mengalami peningkatan. Hal tersebut terjadi karena adanya pemahaman peserta didik mengaplikasikan strategi quick on the draw sehingga mereka aktif ketika berkelompok. Peserta didik juga memperhatikan penjelasan dari guru karena guru menggunakan media gambar untuk menjelaskan materi. Pada siklus II peneliti dan guru melakukan kerjasama dalam memperbaiki kekurangan-kekurangan yang dirasa perlu diperbaiki sehingga pada siklus II menghasilkan hasil yang memuaskan. Selain itu, peningkatan minat belajar peserta didik terhadap mata pelajaran Aqidah Akhlak juga terlihat dari timbal balik antara guru dengan peserta didik. Partisipasi aktif dalam pelaksanaan pembelajaran strategi quick on the draw dan juga dalam memberikan tanggapan melalui menjawab pertanyaan yang dilontarkan oleh guru, peserta didik dapat mengimbangi dengan jawaban-jawaban yang bagus. Aktivitas guru pada siklus I sudah termasuk dalam kategori baik dengan nilai 59. Berdasarkan evaluasi pada siklus I, peneliti sepakat dengan guru mata pelajaran Aqidah Akhlak untuk melakukan siklus II dengan memperhatikan dan memperbaiki kekurangankekurangan berdasarkan refleksi yang dilakukan peneliti dengan guru mata pelajaran Aqidah Akhlak kelas V. Pada siklus II aktivitas guru sangat baik. Terbukti dengan adanya peningkatan nilai dari 59 di siklus I menjadi 88 pada siklus II. Aktivitas peserta didik juga tergolong dalam kategori baik dengan memperoleh nilai 65. Pada siklus I ada beberapa kesulitan, kesulitan pada siklus I disebabkan karena peserta didik belum terbiasa dengan strategi yang digunakan dan masih bingung dengan langkah-langkah strategi quick on the draw. Kondisi peserta didik juga masih belum sepenuhnya siap untuk memulai pelajaran, sehingga kurangnya konsentrasi dalam kegiatan belajar mengajar. Aktivitas peserta didik mengalami kenaikan nilai dari 65 pada siklus I menjadi 90 di siklus II.

Berdasarkan grafik di atas minat belajar peserta didik meningkat dari pra siklus, siklus I sampai siklus II. Pada pra siklus minat belajar peserta didik kategori tinggi dan sangat tinggi 42,22 \% yakni 19 dari 45 peserta didik. Di pra siklus prosentase peserta didik yang memiliki kategori minat belajar sangat tinggi sebesar 8,89\% dengan jumlah 4 peserta didik dan tinggi sebesar 57,78\% dengan jumlah 26 peserta didik. Jadi untuk kategori minat belajar tinggi dan sangat tinggi sebesar 66,67\% dengan 30 peserta didik. Dari hasil minat belajar tersebut dapat dikatakan peserta didik masih kurang dalam minat belajarnya pada mata pelajaran Aqidah Akhlak materi akhlak terpuji. Dalam proses pembelajaran Aqidah Akhlak 
Nur Nafisatul Fithriyah, Nur Latifah, Khusnul Mu'alifah

materi akhlak terpuji diperoleh prosentase siklus II yang mempunyai minat belajar kategori sangat tinggi sebesar 48,89\% dengan jumlah 22 peserta didik dan kategori tinggi sebesar 42,22\% dengan jumlah 19 peserta didik. Jadi jumlah prosentase minat belajar peserta didik kategori sangat tinggi dan tinggi sebesar 91,11\% dengan jumlah 41 peserta didik. Sedangkan pada nilai hasil belajar peserta didik di atas KKM sebesar 68,89\% dengan jumlah 31 peserta didik. Hasil belajar peserta didik pada siklus I ini tegolong dalam kategori tinggi, namun belum mencapai target $80 \%$. Minat belajar peserta didik pada mata pelajaran Aqidah Akhlak materi akhlak terpuji meningkat sekurang-kurangnya 20\% pada setiap siklus. Diukur dari presentase peningkatan minat belajar sebelum dan sesudah menggunakan strategi quick on the draw. Sedangkan pada nilai hasil belajar peserta didik di atas KKM sebesar 83,63\% dengan jumlah 40 peserta didik. Hasil belajar peserta didik pada siklus II ini tergolong dalam kategori sangat tinggi dan sudah mencapai target $80 \%$. Peserta didik mampu menyebutkan dan menerapkan sikap teguh pendirian dan dermawan dalam kehidupan sehari-hari.

\section{Simpulan}

Berdasarkan hasil penelitian yang telah dilakukan, peneliti mendapatkan kesimpulan akhir dengan pencapaian yang positif. Melalu penggunaan strategi quick on the draw pada mata pelajaran Aqidah Akhlak dapat meningkatkan minat belajar peserta didik kelas V MI Darul Hidayah Tulangan Sidoarjo. Minat belajar peserta didik pada mata pelajaran Aqidah Akhlak materi akhlak terpuji sebelum diterapkan strategi quick on the draw tergolong rendah dan sangat rendah sebanyak 26 peserta didik dengan prosentase 57,78 \% dan peserta didik tergolong minat belajar tinggi dan sangat tinggi hanya 19 peserta didik dengan prosentase $42,22 \%$. Minat belajar peserta didik rendah karena sebagian besar peserta didik tidak antusias dalam mengikuti pembelajaran Aqidah Akhlak yang hanya menggunakan metode ceramah. Selain itu, nilai hasil belajar peserta didik dalam kategori rendah. Hal ini terlihat pada jumlah peserta didik yang tuntas belajar sebesar 46,67\% dengan jumlah 21 peserta didik. Dengan perolehan tersebut dikatakan belum berhasil karena belum mencapai target yang dikehendaki yakni mencapai 80\%. Penerapan strategi Quick on the Draw untuk meningkatkan minat belajar Aqidah Akhlak materi akhlak terpuji pada peserta didik kelas V MI Darul Hidayah Tulangan Sidoarjo dilakukan melalui tahapan peserta didik dibagi menjadi 5 kelompok untuk memainkan sebuah permainan. Dalam permainan tersebut peserta didik akan mendapatkan kartu soal untuk didiskusikan dengan 
Nur Nafisatul Fithriyah, Nur Latifah, Khusnul Mu'alifah

anggota kelompok. Peserta didik secara bergantian menjawab pertanyaan dari soal. Kelompok yang pertama menjawab semua soal akan menjadi pemenang. Dalam penerapannya hasil observasi aktivitas guru pada siklus I mendapat nilai akhir 59 (Baik) dan meningkat pada siklus II menjadi 88 (Sangat Baik) serta hasil observasi aktivitas peserta didik pada siklus I sebesar 65 (Baik) dan meningkat pada siklus II menjadi 90 (Sangat Baik). Berdasarkan peningkatan antara siklus I dan siklus II, maka penerapan strategi Quick on The Draw berhasil dan dilakukan dengan sangat baik. Peningkatan minat belajar peserta didik kelas V MI Darul Hidayah Tulangan Sidoarjo setelah diterapkan strategi Quick on The Draw pada mata pelajaran Aqidah Akhlak mengalami peningkatan dari siklus I ke siklus II. Hal ini dapat dibuktikan dengan hasil angket minat belajar dan hasil belajar pada pra siklus, siklus I dan siklus II. Pada pra siklus 42,22\% dengan hasil belajar 46,67\%. Kemudian pada siklus I didapatkan hasil minat belajar 66,67\% dengan hasil belajar 68,89\%. Kemudian pada siklus II meningkat menjadi 91,11\% dengan hasil belajar $88,89 \%$. Sehingga bisa dikatakan berhasil dan bisa mencapi indikator yang telah ditentukan.

\section{Daftar Rujukan}

Djaali. (2008). Psikologi Pendidikan. Jakarta: PT. Bumi Aksara.

Hamalik, Oemar. (2007). Dasar-dasar Pengembangan Kurikulum. Bandung: PT Remaja Rosdakarya.

Hamdani, Ihsan dan A Fuad Ihsan. (2007). Filsafat Pendidikan Islam. Bandung: Pustaka Setia.

Hasan, Hamid. (2009). Evaluasi Kurikulum. Bandung: PT Remaja Rosdakarya.

Iif, A. (2011). Strategi Pembelajaran Sekolah Terpadu. Jakarta: Prestasi Pustaka Publisher.

Majid, Abdul. (2005). Pendidikan Agama Islam Berbasis Kompetensi (Konsep Implementasi Kurikulum 2004). Bandung: Remaja Rosdakarya.

Mubarok, Zaki. (2001). Akidah Islam. Yogyakarta: UII Press.

Mulyasa, E. (2010). Kurikulum Tingkat Satuan Pendidikan. Bandung: Remaja Rosdakarya.

Rahman, Abdul dan Muhbib Abdul Wahab. (2004). Psikologi: Suatu Pengantar. Jakarta: Prenada Media.

Sabri, Alisuf. (2007). Psikologi Pendidikan. Jakarta: Pedoman Ilmu Jaya. 
Nur Nafisatul Fithriyah, Nur Latifah, Khusnul Mu'alifah

Salim, Peter dan Yeni Salim. (1995). Kamus Bahasa Indonesia Kontenporer. Jakarta: Modern Press.

Supardi. (2015). Penilaian Autentik. Jakarta: Raja Grafindo Persada).

Sumadayo, Sumsu. (2013). Penelitian Tindakan Kelas. Yogyakarta: Graha Ilmu.

Surawardi. Telaah Kurikulum Aqidah Akhlak Madrasah Ibtidaiyah.

Suryani, Nunuk dan Leo Agung. (2012). Strategi Belajar Mengajar. Yogyakarta: Ombak.

Syaodih, Nana. (2013). Metodologi Penelitian Pendidikan. Bandung: PT. Remaja Rosdakarya.

Tualeka, Hamzah. (2012). Akhlak Tasawuf. Surabaya: IAIN Sunan Ampel Press. Wahab, Rohmalina. (2015). Psikologi Belajar. Jakarta: PT. RajaGafindo Persada. 